\title{
Correlation between plant distribution and edaphic factors in coastal plains of J azan region, Saudi Arabia
}

\author{
A. A. Salman \\ Botany Department, Faculty of Science, Port Said University, Port Said, Egypt Now, Biology Department, Faculty of Science, Jazan University, Saudi
} Arabia.

\begin{tabular}{l}
\hline ARTICLE INFO \\
\hline Article history: \\
Received on: $05 / 05 / 2015$ \\
Revised on: $28 / 05 / 2015$ \\
Accepted on: $12 / 06 / 2015$ \\
Available online: $20 / 06 / 2015$ \\
\hline Key words: \\
Jazan region, edaphic factors, \\
plant distribution, climate, \\
correlation.
\end{tabular}

\begin{abstract}
Ecological relations between plant distribution and edaphic factors in coastal plains were recorded in 45 stands (20 x $20 \mathrm{~m}$ each) distributed of Jazan region, Saudi Arabia. The main aim of this study was to examine the spatial pattern of vegetation and relationship between vegetation composition and environmental factors on Jazan area. The present study provides quantitative estimates of the vegetation structure and the distribution of the plant communities in coastal plains of Jazan region in relation to the soil properties. The environmental data included elevation, slope degree and exposure. Analysis data involved two steps: classification (using TWINSPAN) and ordination ( using CANOCO). The factors affecting the species distribution and correlation between the vegetation gradients and the edaphic variables are discussed. Ten major community types constitute the major part of the natural vegetation of the study area and are dominated by ten perennials: Acacia tortilis (Forssk.)Hayne., Suaeda monoica Forssk., Tamarix aphylla (L.) Karst., Cyperus conglomeratus Rottb., Ziziphus spina-christi (L.)Willd., Panicum turgidum Forssk., Salvadora persica L., Calotropis procera (willd) R. Br., Tephrosia apollinea (Del.) and Leptadenia pyrotechnica (Forssk)Decne. The complex interaction of different environmental factors in relation to edaphic variables leads to variation of habitat types and different plant distribution communities. Data analysis showed that $\mathrm{pH}$, moisture, electrical conductivity, organic carbon, calcium carbonate, bicarbonate, soil cations: sodium, potassium, calcium, and the sodium adsorption ratio are the main operating edaphic factors in jazan area. The results of this study confirm that the study area is a subtropical desert and belongs floristically to the Sudanian territory and also that therophytes are the most frequent lif-form in this region.
\end{abstract}

\section{INTRODUCTION}

The southwestern region of Saudi Arabia is unique in regard to its nature, landform, climate and water availability [1]. Several ecological studies have been done in some of the phytogeographical regions of Saudi Arabia [2], [3], [4], [5], [6] [7], [8], [9], [10] Most of these studies were based on qualitative field observations and interpretation of the authors. Although these studies were focusing on preparing florisic lists [2] and [10], some of them gave detailed description of the plant communities in relation to some ecological factors e.g. edaphic conditions, climate, aridity and topography [9]; [11]; [5], and [8], and found that the complex interaction of different environmental factors in relation to altitude leads to variation of habitat types and different plant communities and vegetational belts. In this regard Jazan region has received the least attention [12] identified Jazan region geomorphologically, by three main sectors; A) Mountains: E1Sarwat mountains, B) Plains: 'Tihamah' coastal plains, and C) Islands: including those between Jizan city and Farasan islands.

* Corresponding Author

Mail id: Dr_Ashraf11 [at] yahoo.com
Ecologically, [13] and [14], distinguished five ecosystems in Tihamah coastal plains namely: shoreline, sand formations, salt marshes, wadis and rocky hills. [15] discussed vegetation, species diversity and floristic relations in south-western Saudi Arabia and demonstrated remarkable change with altitude. [16], gave detailed description of usages of herbal remedies for the management of vaginal infection among women in Jazan Area, Saudi Arabia. The aim of this paper is to examine the spatial pattern of floristic composition at species and community levels and to clarify the correlation between plant distribution and edaphic factors of Jazan region, Saudi Arabia.

\section{MATERIALS AND METHODS}

2.1 Study area

Jazan region located in the southwestern part of Saudi Arabia (lat. $16^{\circ} 54^{\prime} \mathrm{N} \&$ long. $42^{\circ} 33^{\prime} \mathrm{E}$ ). The research area is on coastal plains of Jazan region. The current study was performed in Jazan district, Saudia Arabia (Figure $1 \mathrm{~A}$ and B). The region is located in the southwestern part of the Kingdom of Saudi Arabia between the longitudes $(42-43)$ east and latitudes $(16-17)$ in the north, and bounded on the north and east Asir region to the west of 
the Red Sea along the coastline for about $330 \mathrm{~km}$, and from the south and south-east as the Republic of Yemen, as has the average width of the area from east to west of about $100 \mathrm{~km}$. The study period was for one year (March 2011 to March 2012). The present study focuses on using 45 stands (20 x $20 \mathrm{~m}$ each) (Fig. $2 \mathrm{~A}, \mathrm{~B}, \mathrm{C}$, $\mathrm{D}$, and $\mathrm{E})$, represented and covered the main physiographic variations of Jazan region. Geologically, the study area belongs to the greater Afro-Arabian shield which is a part of the Precambrian crustal plate, generally exposed and locally covered by Tertiary volcanic rocks [17].

According to the climatic normals of Jazan region (averages of 2000-2010), Jazan area is generally hot during summer with the mean monthly air temperature ranges between 30 ${ }^{\circ} \mathrm{C}$ during January and $40{ }^{\circ} \mathrm{C}$ during August. The maximum rainfall $(18.0 \mathrm{~mm})$ was recorded during December, while the minimum ( $0.8 \mathrm{~mm}$ ) was attained during June. The climate diagram (Fig. 3) demonstrates dry period prevailing all the year round. The mean annual relative humidity of the study area is about $64.9 \%$. The wind speed has a narrow range of variation (11$12.2 \mathrm{~km} / \mathrm{h}$ ). Stormy wind with fine aeoline particles prevails during July-August with a northwestern direction [18].

\subsection{Research design and sampling}

Forty- five stands (20 x $20 \mathrm{~m}$ each) were selected and measured in the study area. In selecting each stand, care was taken to ensure reasonable degree of physiographic and physiognomic homogeneity of both habitat and vegetation Sampling sites were selected, representing the most common habitats and herbaceous communities in the data as described by [13], [19], [15], and [20]. Soil samples measured and described by [13], [15], and [20].

A count-floristic list was carried out for each stand and relative frequency and density for each perennial species were calculated, while the relative cover was determined using the line intercept method. The sum of the relative frequency, relative density and relative cover gave the importance value (IV) for perennial species. The annual species were recorded in each stand. Composite soil samples taken from each stand to a depth of $50 \mathrm{~cm}$. Soil samples were air-dried, crushed and $\operatorname{sieved}(<2 \mathrm{~mm})$ as described by [21], [22] and [23]. The Electrical conductivity (EC), $\mathrm{pH}$ and soluble ions were measured in soil saturation extracts. $\mathrm{Na}$ and $\mathrm{K}$ were measured by flame emission spectroscopy; $\mathrm{Ca}$ and $\mathrm{Mg}$ by atomic absorption spectroscopy; $\mathrm{Cl}$ and SO4 by visible spectrophotometry;Organic matter (OM) was measured using a modified Walkley \& Black method and total inorganic carbonates (TIC) was analyzed using a pressure calcimeter [24].

\subsection{Data Analysis}

Vegetation and related environmental factors were analyzed using ordination techniques. A direct ordination method was used to enable us to test the environmental variables collected releves . The analyses were conducted using CAP and Canoco program (Version 4.5) [25], [26]. Detrended Correspondence Analysis (DCA) was used to detect the length of the environmental gradient. Then, Canonical Correspondence Analysis (CCA) was applied because the data set was relatively heterogeneous and therefore, the length of ordination axes in DCA was relatively long [27]. Clustering methods were used to determine the patterns underlying species distribution and how plant communities may delineate habitat types in the study area. Two Way Indicator Species Analysis [28] was used for this purpose. Floristic identification are according to [29], [30], [31], [32] and [33], [34], [35].
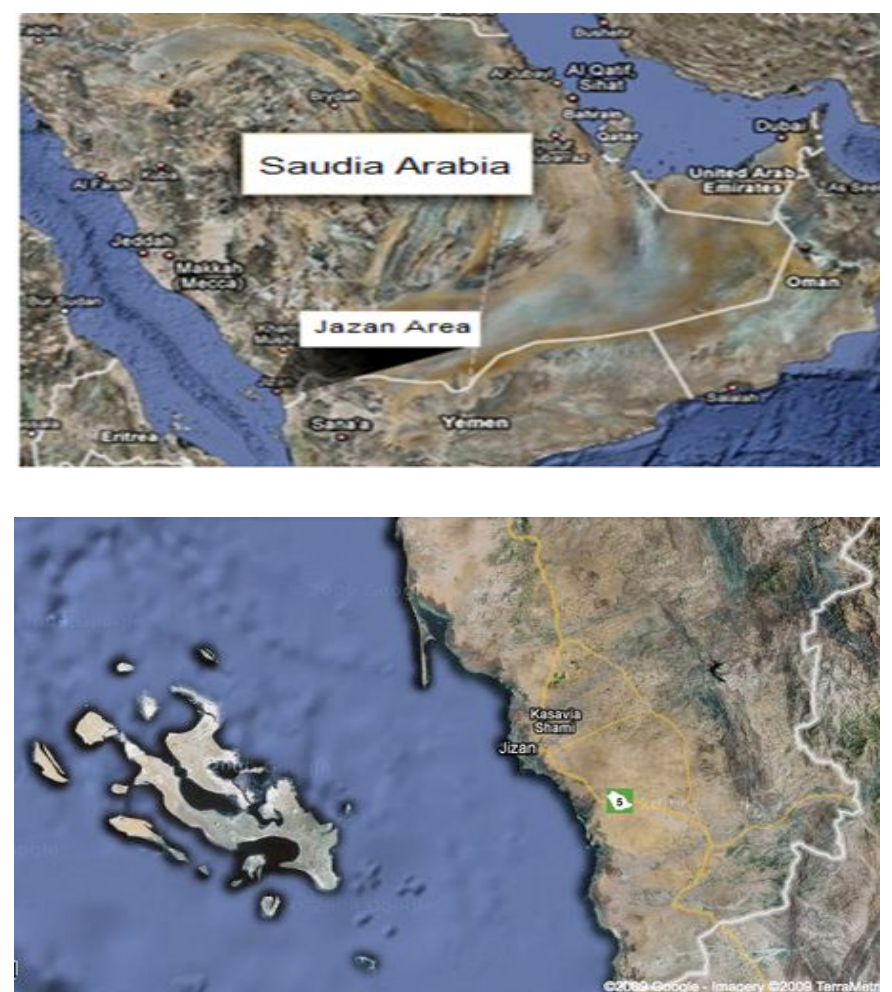

Fig. 1: Showing (a) Saudi Arabia (b) Jazan Area location and the study area.

\section{RESULTS}

\subsection{Floristic patterns}

Forty five stands represent the floristic patterns along the coastal plains of Jazan region, Saudi Arabia, area of the study (Fig. 2). 81 plant species related to 29 families were recorded in the study area. They constituted 42 perennial and 39 annual species: Gramineae 28.1\%, Leguminosae 13.2\%, Zygophyllaceae, Euphorbiaceae and Solanaceae together 11.1\%, Asclepiadaceae, Amaranthaceae, Cappariaceae and Cruciferae make up $18.3 \%$, while the other 20 families make up $29.3 \%$ of the total (see appendix). The most common perennials recorded were: Tephrosia apollinea, Dipterygium glaucum, Panicum turgidum and Acacia tortilis (presence percentage: 40.0 - $57.5 \%$ ). Salvadora persica, Ziziphus spina-christi, Leptadenia pyrotechnica, Calotropis procera, Suaeda monoica, Aerva javanica, Indigofera spinosa Heliotropium arbainense, and Cassia italica attain presence percentage ranging between $(20.0$ - 35\%). The most common annuals in the study area are: Cenchrus ciliaris, Chloris virgata, Tribulus terrestris, T. longipetalus, Euphorbia prostrata, 
Schouwia thebaica, and Trianthema portulacastrum. Therophytes constituted about $51.9 \%$ of the total flora in the study area, followed by Chamaephytes $(30.3 \%)$, Phanerophytes $(10.9 \%)$, and Cryptophytes $(3.1 \%)$, Hemicryptophytes $(3.8 \%)$. The majority of the recorded species belong to the sudanian and tropical territories.

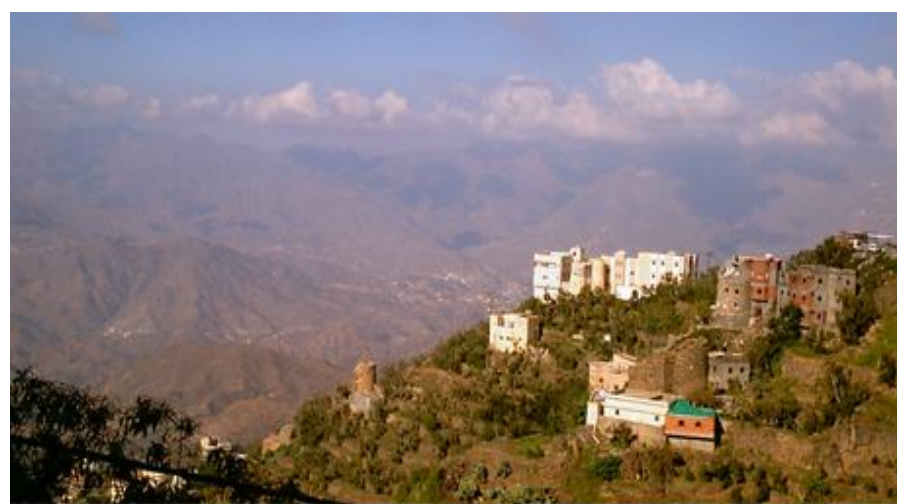

A
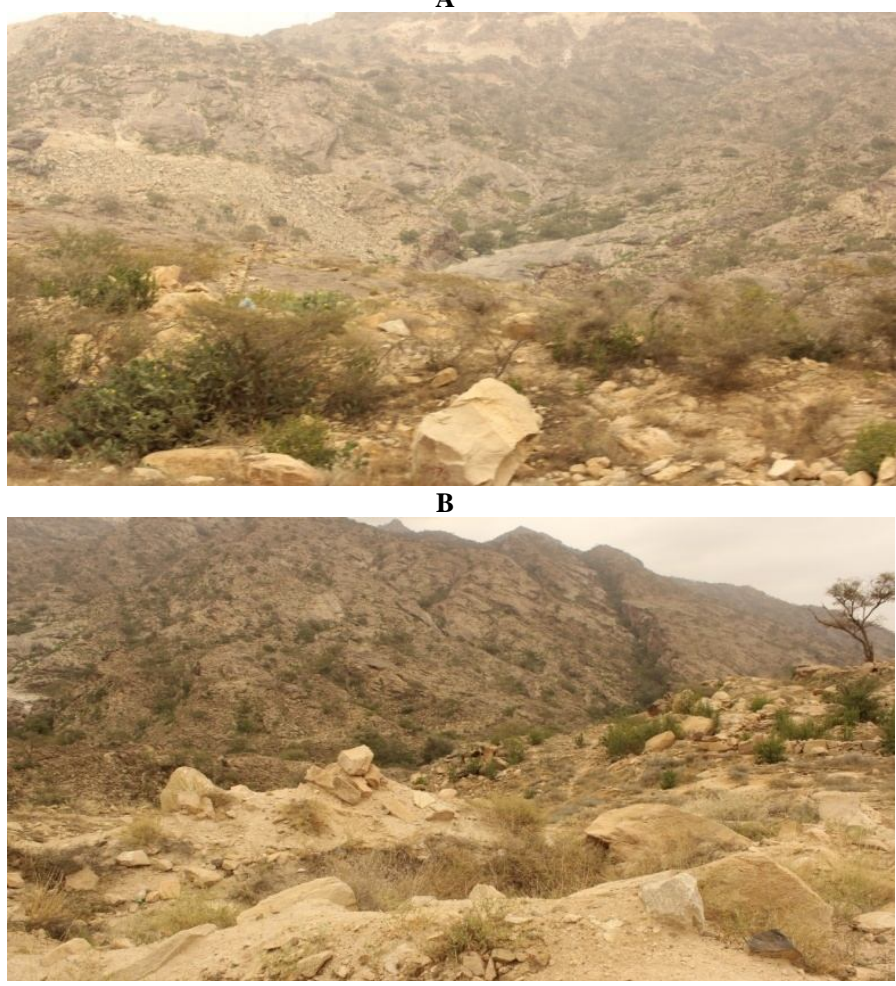

C

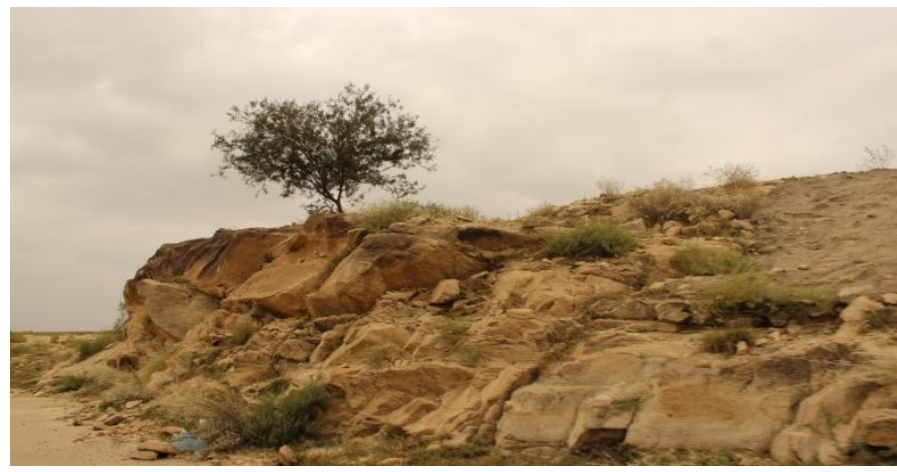

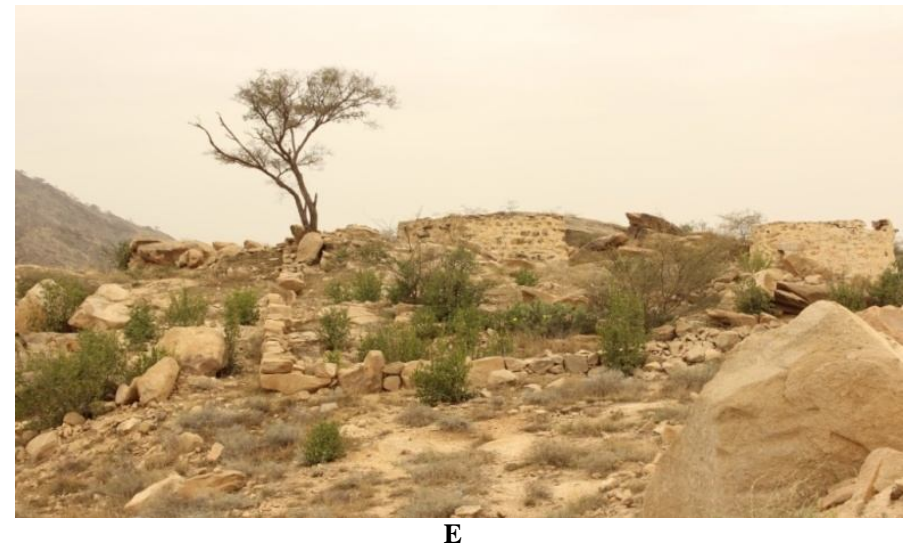

Fig. 2: (A,B,C,D and E) A showing Plant diversity in location of Jazan region.

\subsection{Classification of Plant Community Types}

The application of TWINSPAN classification technique on the Floristic Patterns: 81 floristic composition of the 45 naturalized stands led to classify them into 15 vegetation groups gave at level 6,13 at level 5 and 10 gave at level 4 (Fig 4). Segregation between 10 groups along DCA axes 1 and 2 are indicated in Fig. 3. Characteristics of the 10 vegetation groups identified at level 4 of TWINSPAN are indicated in table 1. The means of the soil characteristics of the 10 vegetation groups identified at level 4 of TWINSPAN are shown in Table 2.

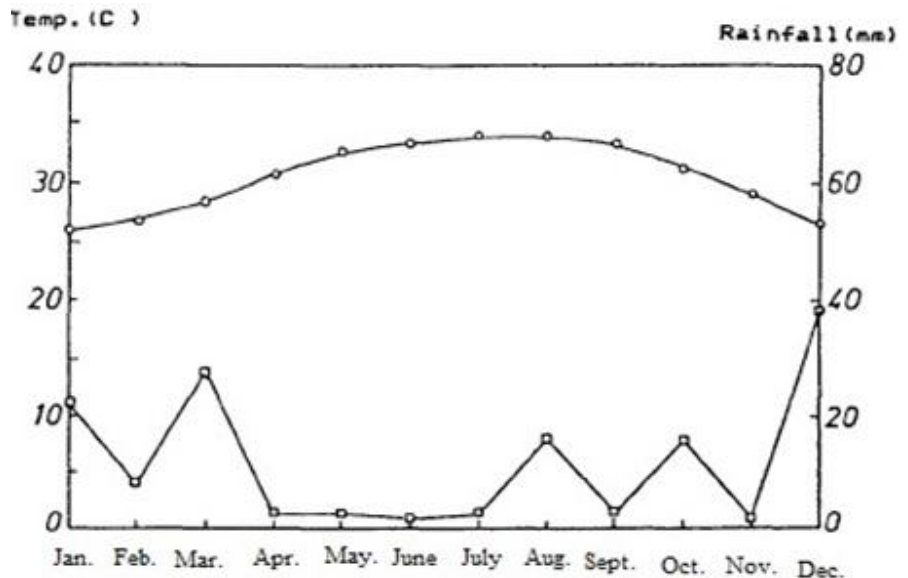

Fig. 3: The Climate Diagram of jazan region.

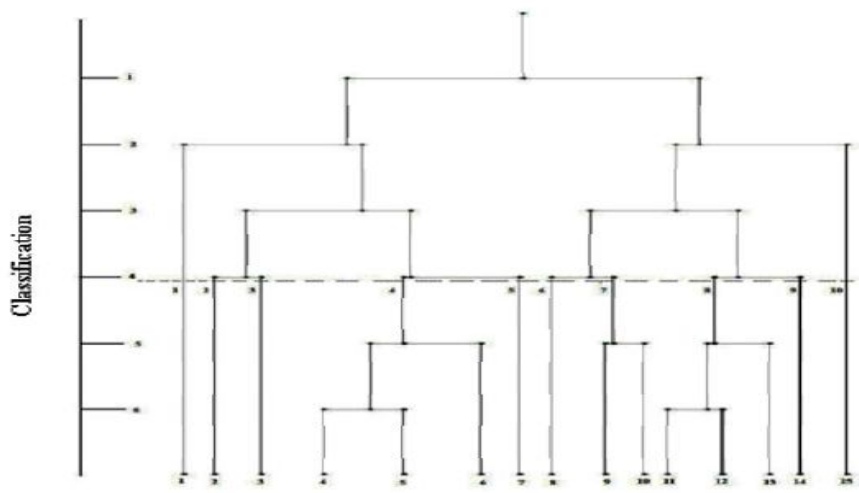

Fig. 4: Dendogram resulting from the Two-Way Indicator Species Analysis (TWINSPAN) of 45 Stands (Vegetation survey) in Jazan region. 


\subsection{Relation between the Environmental Factors and species distribution}

DCA and CCA ordination were used to verify relationships between species and the environment in the study area. The DCA ordination revealed that the first gradient is the longest one, explaining about $9.8 \%$ of the total species variability, whereas the second and higher axis is less. Also, the second axis is very well correlated with the environmental data $(r=0.845)$ and the correlation for the other axis is considerably lower. These results suggest that the whole data set is governed by a single gradient. The sum of all canonical eigenvalues in printout corresponds to the sum of all canonical eigenvalues in the corresponding canonical analysis. The percentage variance of the species-environment relationship values represents percentage of this value. The number of axis scores calculated for a speciesenvironmental variable bi-plot is restricted in DCA, by default, to two. This is why the explained variability for the third and fourth axis is shown as 0 . The projection of environmental variables reveals that the first axis is negatively correlated with soil $\mathrm{pH}$ gradient, concentration of soil cations ( $\mathrm{Ca}, \mathrm{K}$ and $\mathrm{Na}$ ), concentration of SO4 concentration of total dissolved salts,and electrical conductivity, and positively with concentration of cation $(\mathrm{Mg})$ and soil organic matter, altitudinal gradient, the concentration of anions ( $\mathrm{HCO}$ and $\mathrm{Cl}$ ), and also with $\mathrm{CaCO}$ gradient (Fig 5). The positions of arrows for environmental variables suggest that there is a group of variables that are mutually highly positively correlated (Exposure, organic matter, $\mathrm{SO}, \mathrm{Cl} \& \mathrm{CaCO}$ ) and negatively correlated with (Alt, $\mathrm{pH}, \mathrm{Na}, \mathrm{K}$ ).
A closer inspection of the correlation matrix in the CANOCO Log View shows that the variables are indeed correlated, but in some cases the correlation is not very high. The correlation matrix also confirms that the correlation of all the measured variables with the second axis is rather weak. Now we can continue with the direct (constrained) ordinations. While in DCA we first extract the axes of maximum variation in species composition and only then fit the environmental variables, we directly extract the variation that is explainable by the measured environmental variables. A Monte Carlo permutation test suggested that both the test on the first axis is not significant $(\mathrm{P}=$ 0.312 ) and the test on all axes (on the trace) are significant ( $\mathrm{P}=$ 0.02 with 499 concentration permutations, which is the maximum under the given number of permutations). However, the $F$ value is much higher for the test on the first axis $(F=1.831)$ than for the test on the trace $(\mathrm{F}=1.279)$ (Table 3 ). Comparing this summary with that from the DCA used before, one will notice that the percentage variance explained by the first axis is very close to that explained by the first axis in the unconstrained DCA (6.3 in comparison with 9.8) and also that the species environment correlation is only slightly higher. This suggests that the measured environmental variables are those responsible for species composition variation. And indeed, in the ordination diagrams of DCA and CCA (not shown here), the first axis of CCA is very similar (both for the species and for the sample scores) to the first axis of DCA. However, the second axis differs: the CCA shows a remarkable arch effect-the quadratic dependence of the second axis on the first one.

Table 1: Characteristics of the 10 vegetation groups identified at level 4 of TWINSPAN on the 45 naturalized stands in Jazan area $(V G=v e g e t a t i o n ~ s t a n d s, ~ P \%=$ probability percent).

\begin{tabular}{cccccc}
\hline VG & No. of stands & P\% of stands & No. of species & P\% of species & Dominant species \\
\hline 1 & 2 & 4.4 & 14 & 19.42 & Acacia tortilis $($ Forssk.)Hayne \\
2 & 4 & 8.9 & 36 & 39.81 & Suaeda monoica Forssk \\
3 & 2 & 4.4 & 20 & 24.27 & Tamarix aphylla $(\mathrm{L}$.) Karst \\
4 & 14 & 22.2 & 52 & 54.37 & Cyperus conglomeratus Rottb \\
5 & 1 & 2.2 & 15 & 19.42 & Ziziphus spina-christi $($ L.)Willd \\
6 & 3 & 6.7 & 21 & 25.24 & Panicum turgidum Forssk \\
7 & 5 & 11.1 & 25 & Salvadora persica $\mathrm{L}$ \\
8 & 8 & 17.8 & 25 & 29.13 & Calotropis procera $($ willd) R. Br \\
9 & 3 & 6.7 & 9 & 13.59 & Tephrosia apollinea $($ Del.) \\
10 & 3 & 6.7 & 15 & 19.42 & Leptadenia pyrotechnica (Forssk)Decne \\
\hline
\end{tabular}

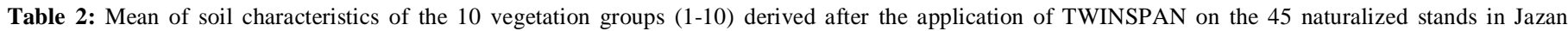
area(VG=vegetation stands, F=frequency, Sig.=significance)

\begin{tabular}{|c|c|c|c|c|c|c|c|c|c|c|c|c|}
\hline VG & 1 & 2 & 3 & 4 & 5 & 6 & 7 & 8 & 9 & 10 & $\mathbf{F}$ & Sig. \\
\hline$\overline{\mathrm{pH}}$ & 7.9 & 8.0 & 8.2 & 8.2 & 7.7 & 8.2 & 8.2 & & 8.2 & 8.3 & 4.296 & .000 \\
\hline $\mathrm{EC}(\mu \mathrm{s} / \mathrm{cm})$ & 175.0 & 105.6 & 106.2 & 107.4 & 317.5 & 90.6 & 59.8 & 89.5 & 171.9 & 78.3 & 7.051 & .000 \\
\hline T.D.S (ppm) & 361.8 & 217.5 & 218.8 & 221.3 & 658.3 & 186.3 & 122.3 & 184.0 & 355.3 & 160.6 & 7.053 & .000 \\
\hline water content & 0.4 & 0.7 & 16.6 & 0.7 & 0.3 & 0.7 & 1.0 & 0.8 & 0.6 & 0.3 & 14.226 & .000 \\
\hline OM \% & 5.3 & 5.1 & 6.7 & 6.1 & 6.0 & 4.6 & 5.0 & 6.4 & 5.6 & 5.0 & 1.652 & .108 \\
\hline $\mathrm{CaCO} \%$ & 23.3 & 20.1 & 22.3 & 22.1 & 19.3 & 20.1 & 17.0 & 14.7 & 17.5 & 23.6 & 6.665 & .000 \\
\hline $\mathrm{Ca}++(\mathrm{meq} / \mathrm{L})$ & 20.3 & 21.3 & 16.3 & 19.7 & 15.0 & 18.3 & 14.5 & 15.8 & 26.7 & 12.5 & 2.416 & .015 \\
\hline $\mathrm{Mg}++(\mathrm{meq} / \mathrm{L})$ & 12.1 & 9.9 & 16.1 & 9.4 & 47.4 & 7.1 & 7.0 & 8.8 & 5.9 & 12.4 & 16.364 & .000 \\
\hline $\mathrm{Na}+(\mathrm{ppm})$ & 24.1 & 23.5 & 18.5 & 40.7 & 43.2 & 19.3 & 52.7 & 48.8 & 28.8 & 28.4 & 1.689 & .098 \\
\hline $\mathrm{K}+(\mathrm{ppm})$ & 26.6 & 33.0 & 27.4 & 47.3 & 24.3 & 27.2 & 35.6 & 52.6 & 31.0 & 63.5 & 2.901 & .004 \\
\hline $\mathrm{HCO} 3(\mathrm{meq} / \mathrm{L})$ & 13.5 & 12.3 & 13.5 & 10.4 & 22.0 & 9.5 & 8.8 & 7.6 & 9.6 & 9.5 & 14.079 & .000 \\
\hline $\mathrm{Cl}-(\mathrm{meq} / \mathrm{L})$ & 13.0 & 16.8 & 14.0 & 14.2 & 19.6 & 13.3 & 13.0 & 13.8 & 15.4 & 12.8 & 4.420 & .000 \\
\hline $\mathrm{SO} 4(\mathrm{meq} / \mathrm{l})$ & 75.0 & 84.8 & 62.5 & 60.5 & 112.5 & 59.5 & 50.7 & 57.8 & 70.1 & 54.5 & 6.216 & .000 \\
\hline
\end{tabular}


Table 3: Summary of Monte Carlo test.

Test of significance of first canonical axis: eigenvalue $=0.450$

F-ratio $=1.831$

$\mathrm{P}$-value $=0.3120$

Test of significance of all canonical axes : Trace $=3.164$

F-ratio $=1$

$\mathrm{P}$-value $=0.0200$

(499 permutations under reduced model).

This pattern also appears in the Summary table, where the first axis explains more than the second, third and fourth axes do together.

Table 4: Environmental parameters used in the CCA and their eigen values.

\begin{tabular}{|c|c|c|c|c|c|}
\hline$\underline{\text { Axes }}$ & $\underline{\mathbf{1}}$ & $\underline{\mathbf{2}}$ & $\underline{\mathbf{3}}$ & $\underline{4}$ & $\begin{array}{l}\text { Total } \\
\text { inertia }\end{array}$ \\
\hline Eigenvalues & 0.450 & 0.431 & 0.305 & 0.273 & 7.092 \\
\hline $\begin{array}{l}\text { Species-environment } \\
\text { correlations }\end{array}$ & 0.913 & 0.901 & 0.909 & 0.907 & $\underline{---}$ \\
\hline $\begin{array}{l}\text { Cumulative percentage } \\
\text { variance }\end{array}$ & & & & & \\
\hline of species data & 6.3 & 12.4 & 16.7 & 20.6 & -- \\
\hline $\begin{array}{l}\text { of species-environment } \\
\text { relation }\end{array}$ & 14.2 & 27.9 & 37.5 & 46.1 & -- \\
\hline Sum of all eigenvalues & -- & -- & -- & -- & 7.092 \\
\hline $\begin{array}{l}\text { Sum of all canonical } \\
\text { eigenvalues }\end{array}$ & -- & -- & -- & -- & 3.164 \\
\hline
\end{tabular}

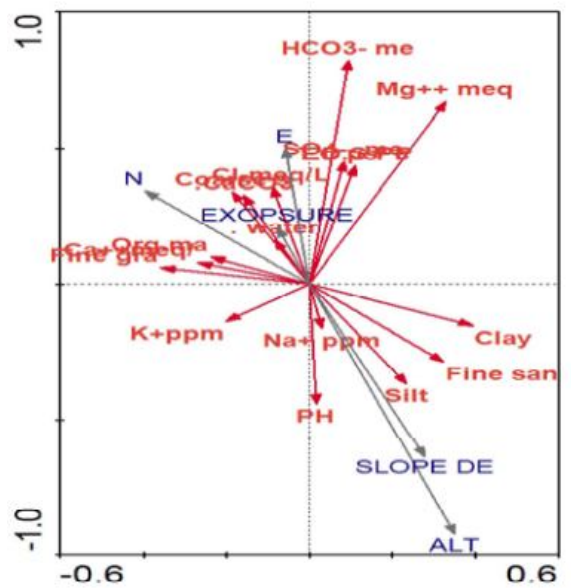

Fig. 5: The Topology - environmental variables bi-plot of CCA with environmental variables selected by the forward selection procedure

\section{DISCUSSION}

\subsection{Floristic Patterns and Ecological Gradients:}

For the long time ago, the correlation pattern in vegetation and gradients in environmental parameters was estimated by [36], [37]. Multivariate analysis including classification and ordination can provide more detailed and comprehensive information on the patterns in vegetation and the response of plant species to the underlying gradients [38], [39].

According to Koppen's climatic system, Coastal plains of Jazan region, Saudi Arabia, are lie within the tropical dry hot zone of the desert, characterized by high temperature (between $30{ }^{\circ} \mathrm{C}$ during January and $40{ }^{\circ} \mathrm{C}$ during August), moderate relative humidity $(64.9 \%)$, and low rainfall $(0.8-19.0 \mathrm{~mm})$. Summer rainfall is connected to influence of Indian monsoon, while the winter rainfall is related to the Mediterranean regime [32], [12]. Since the local climate over the coastal plains of Tihamah is almost uniform, the distribution and species composition of the plant communities would appear to be more affected by the various edaphic factors.

According to [32], the southern Arabian phytogeographical region (including Yemen) contains 200025,000 species of flowering plants. The most important tropical genera in Arabia are Acacia, Indigofera, Euphorbia,Solanum, Aristida, Caralluma, Tephrosia, Pulicaria, Barleria, Grewia, Commiphora and Cadaba. About $20 \%$ of the floristic elements of southern Arabia are endemic [40]. The present study recorded 81 species in the coastal plains of Jazan region, of which 42 are perennials and 39 are annuals. [41], regarded Southern Arabia and Ethiopia as a single phytogeographical unit, the Eritreo-Arabian province. In the meantime, [42] reported that the floristic composition of Southwest Arabia, especially those of the interior deserts show some floristic affinities to the Irano - Turanian and Mediterranean territories.

The study area represents a continuation of the Sudan region which has close similar climatic and topographic features, therefore most of the recorded species are Afro-Tropical ones, and belong to the Paleotropic kingdom [43]

Scrub savanna include a wide range of vegetation types and are defined in many different ways. [44], grouped savanna in three groups: climatic, edaphic and anthropogenic savanna. Synthetically, savanna can be characterized by a continuous herbaceous layer and a discontinuous cover of shrubs and trees [45].

Besides spatial variation in the species composition of plant Communities, the composition of life-forms (see [46] for definitions) reflects the response of vegetation to variation in certain environmental factors. The life-form of a plant is thought to be either a hereditary adjustment to environment [13], or represents the residual effects of some historical, climatic or biotic conditions on the population of the plant [47] .In this study, therophytes are the most frequent life-form in the study area, followed by chamaephytes, phanerophytes, cryptophytes, hemicryptophytes respectively. The dominance of both therophytes and chamaephytes over other life-forms in Tihamah coastal plains seem to be a response to the hot dry climate, topographic variations, human and animal interference. A comparison of the life-form spectra of both the Eastern and Southern regions of Saudi Arabia [33], with the study area, indicates that the Southern region contains more chamaephytes,and therophytes and less hemicryptophytes (27.4, $51.2 \& 4.8 \%$, represently than the Eastern region $(23,46$ and $6 \%$, respectively). In the meantime, it contains almost the same number of cryptophytes c. $7.0 \%$ and about half of the phanerophytes. The classification of the stands represented within the study area using the agglomerate cluster analysis led to the identification of ten major plant community types forming the major part of the natural vegetation. The communities were dominated by ten perennials: 
Ziziphus spina-christi, Calotropis procera, Leptadenia pyrotechnica, Suaeda monoica, Panicum rurgidum, Salvadora persica, Acacia tortilis,Tamarix mannifera and Cyperus conglomeratus. [7] and [11]. described similar communities along the Saudi Red Sea coast. [32],described the habitats and plant communities in Tihamah plains on the Red Sea coast of Yemen. [48], [49] and [50], described similar communities along the Egyptian Red Sea coast. The dense grow[50] th of annual species in the study area, especially after rainfall is controlled by fluctuation of both temperature and rainfall. The application of TWINSPAN classification technique on the floristic composition of the 45 naturalized stands led to classify them into 15 vegetation groups at level 6,13 at level 5 and 10 at level 4 (Fig 5). Shortly after rainfall, the soil surface of the study area is covered with dense growth of annual species,e.g. Zygophyllum simplex, Chloris virgata, Cenchrus ciliaris, Tribulus terrestris, T. longipetalus, Schouwia thebaica, Trianthema portulacastrurn, and Boerhavia diffusa. The amount and seasonality of rainfall together with the high temperature controls the growth of these communities.

[51], reported similar communities in the coastal plain, foothills and wadis of the gulf of Elat and demonstrated that these communities tolerate lower annual temperature $\left(23-26{ }^{\circ} \mathrm{C}\right)$ and receive higher annual rainfall $(5-30 \mathrm{~mm})$ as compared to habitat condition in Tihamah plains (29-38 ${ }^{\circ} \mathrm{C} \& 0.8-19 \mathrm{~mm}$, respectively). [47], reported that Ziziphus spina-christi grows in diffused pattern on the Mediterranean coastal plains and in the Jordan Valley, and that Tamarix aphylla has a very wide range of distribution in North \& South Africa and Western Asia, and described Suaeda monoica as a thermophilic species which cannot withstand even mild winter. [52], reported Acacia tortilis as a Sudanian tree dominating the more arid places of the southern coast of Sinai. [7], and [11] described similar communities along the coastal plains of the Saudi Red Sea coast. [32], gave detailed description of the habitats and plant communities in Tihamah plains on the coast of Yemen. [48] and [50], described similar communities along the Egyptian Red Sea coast. On the tropical scale, [45] detected some similar communities on an arid misty mountain plateau in Sudan and concluded that the species composition, at all spatial scales, is directly or indirectly related to variation in temperature and moisture. [53] , while dealing with the vegetation types and patterns in Senegal, described communities ofCalotropis procera, Acacia tortilis and Ziziphus spp.in the Sahelian grassland.

The correlation analysis demonstrated that $\mathrm{pH}$, bicarbonate, sodium, potassium, and calcium to sodium adsorption ratio have high significant correlation, while soil $\mathrm{pH}$, moisture, electrical conductivity, bicarbonate and calcium carbonate showed significant correlations as (Fig. 5). The ratio $\mathrm{Na}+/(\mathrm{Ca}+++\mathrm{Mg}+$ $+)$, and $\mathrm{K} \% /(\mathrm{Ca} \%+\mathrm{Mg} \%)$ determines the adsorption pattern of these cations by the exchange complex [47]; [54]. However, our results showed that silt and clay content, organic matter and electrical conductivity are mainly related to vegetation distribution. In addition, [55] reported that edaphic factors provide the primary explanation for describing the distribution of plant communities in the Western Desert of Egypt. Soil texture controls dynamics of soil organic matter in many simulation models or organic matter decomposition and formation [56], [57], [58], and influences infiltration and moisture relation and the availability of water and nutrients to plants [59]. Under the condition of low and irregular rainfall which prevail in the study area, local topography and water redistribution within the local landscape [60].

In accordance with the other studies of the desert ecosystems [61]; [5]; [7], [62], the present study indicated that the distribution of the recognized plant communities in Jazan region is affected mainly by physiographic features, climatic conditions as well as soil attributes, and that these communities are modified both in their distribution and abundance by the effects of some other factors that threaten the plant life in Tihamah area including: a) Agricultural activities, b) Heavy grazing, c)Woodfuel cutting and d)Termites [13].

Spatial distribution of plant species and communities over a small geographic area in desert ecosystems is related to heterogeneous topography and landform pattern [63]. The heterogeneity of local topograohy, edaphic factors, microclimatic conditions lead to the variation in the distributional behavior of the plant associations of the study area.

In conclusion, the present study showed that the vegetation in the study area belongs to the Sudanian territory. Edaphic factors indicated and play an important role in the distribution of the different plant community types. Human and animal impacts modified the distribution and abundance of the plant species and life-form spectrum.

\section{ACKNOWLEDGEMENTS}

This work was carried out while Salman, A. A. is working as a teaching staff as assistant teacher in Biology department, Faculty of science, Jazan University, Saudi Arabia. I wish to express my deepest gratitude to Mr. M. A. Nabih an assistant lecture in Faculty of Science, Biology department, Jazan University, Saudi Arabia, field work assistant.

\section{REFERENCES}

1. Abulfatih, H. A. Wild plants of Abha and its surroundings.Proceeding of the Saudi Biol. Soc. 1981; 5: 143-159.

2. Vessey-Fitzgerald, D.F. Vegetation of the Red Sea coast south ofJeddah, Saudi Arabia. J. Ecol. 1955; 43: 477-

3. Khodair, A. Ecological studies in Riyadla district. M.Sc. Thesis, Ain Shams University, Egypt. 1963.

4. Popov, G. \& Ziller, W. Ecological Survey Report on the 1962 survey in the Arabian Peninsula, U.N. Special Fund, Desert Locust Project Programme Report (FAO(U'NSF/DC/ES6). 1963; 94 pp.

5. Batanouny, K. G. Vegetation along the Jeddah-Meccaroad: patteren and process as affected by human impact. J. of Arid Environ. 1979; 2: 21 30.

6. EI-Sharkawi, H.M., Fayed, A.A. \& Salama F.M. Vegetation of inland desert wadis in Egypt. II. Wadi E1-Matuli and Wadi E1-Qarn. Feddes Reportorium, 1982; 93: 125-133.

7. Zahran, M. A. Vegetation types of Saudi Arabia. Fac. of Meteoro. and Arid Environ. King Abdulaziz Univ. press. Jeddah. 1982; pp. 61.

8. Batanouny, H. H. \& Baeshin, N. A. Plant communities along MedinaBadr road across the Hedjaz mountains,Saudi Arabia. Vegetation. 1983; 53: 33-43 
9. Younes, H. A., Zahran, M. A. \& E1-Qurashy, E.M. Vegetation-Soil relationship of a sea-inlandward transect, Red Sea Coast, Saudi Arabia. J. of Arid Environ. 1983; 6: 349- 356

10. Baierle, H. V., El-Sheikh, A. M. \& Frey, W. Vegetation and Flora im mittleren Saudi Arabien (AI-Taif-Riyad), Beih. Tubinger Atlas Vorder Orient, Reihe A (Naturwissenschaften), 22: Wiesbaden. 1985.

11. Zahran, M. A., Younes, H. A. \& Tawil, B. A. Ecology of four community types: Red Sea coastal desert, Saudi Arabia. J. of Coastal Res. 1985; 1 (3): 279-288.

12. AI-Sheriff, A. S. The Geography of Kingdom of Saudi Arabia. Part II: The SouthWestern Province. Dar E1-Marikh. Riyadh. 1984; pp 483.

13. E1-Demerdash, M.A., A. K. Hegazyt and A. M. Zilay. Distribution of the plant communities in Tihamah coastal plains of Jazan region, Saudi Arabia. Vegetatio. 1994; 112: 141-151.

14. E1-Demerdash,M.A., A. K. Hegazyt and A. M. Zilay. Vegetation-soil relationships in Tihamah coastal plains of Jazan region, Saudi Arabia.Journal of Arid Environments. 1995; 30:161-174.

15. Hegazy, A.K., El-Demerdash, M.A., and Hosni, H.A. Vegetation, species diversity and floristic relations along an altitudinal gradient in south-west Saudi Arabia. Journal of Arid Environments. 1998; 38: 313.

16. Zaghloul, and Salman, A. A. Usage of Herbal Remedies for the Management of Vaginal Infection among Women in Jazan Area at Saudi Arabia. The Egyption Socity For Enviromental Science. CATRINA), 2012; 7 (1):87-96.

17. Schmidt, D. L., Hadley, D. G., Greenwood, W. R., Gonzalez, L. Coleman, R. G. \& Brown, G. F. Stratigraphy and Tectonism of the Southern part of the Precambrian Shield of Saudi Arabia: U.S. Geological Survey, Saudi Arabian Project Report. 1972; pp. 136-139.

18. Anonymous. Surface Annual Climatological Report. 1964-1990. Climate Directorate, Jazan Airport (personal communication). 1990.

19. Moustafa, A. and J. Klopatek. Vegetation and Landforms of the St. Katherine area, Southern Sinai, Egypt. Journal of arid Environments, 1995; 30: 385-395.

20. Salman, A. A. Ecological studies on vegetation of wadi systems on South Sinai, Egypt, Ph.D. Thesis, Botany Department, Fac. of Sci., Ismailia, Suez Canal University, Egypt, 2004; pp: 188.

21. Ball , D.F. Site andsoils . in: Champan,S.B. (ed.):mendos in plant ecology Blackwell Scientific Publications. 1976; Pp. 297-367.

22. Hausenbuiller.R. L. Soil Science Principles and Practices. 3ed., C. Brown Company Publishers, 1985; 610 pp.

23. Wild,S. A., and Voigt, G. k., and Lyer, J. G. Soil and plant analysis for tree culture. Edition by Golden Chester. Applied Science Publishers. 1972; 172 pp.

24. Page, A. 1., Miller, R. H \& Keeney,D. R. Methods of soil analysis . part 2- chemical and microbiological properties, Agronomy, 1982; 9 (2), Madison, WI

25. Ter Braak, C. and P. Smilauer. CANOCO Reference Manual and Cano Draw for Windows User's Guide: Software for Canonical Community Ordination Version 4.5). MicrocomputerPower, Ithaca, New York. 2002.

26. Hejcmanova-Nezerkova, P. and M. Hejcman. A canonical correspondence analysis CCA) of the vegetation-environment relationships in Sudanese savannah, Senegal. South African Journal of Botany, 2006; 72: 256-262.

27. Leps, J. and P. Smilauer. Multivariate Analysis of Ecological Data Using CANOCO. Cambridge University Press, Cambridge, UK. 2003; pp: 282.

28. Hill, M.O. TWINSPAN-A FORTRAN Programme for Arranging Multivariate Data in an Ordered Two-way Table by Classification of Individuals and Attributes. Cornell University, Ithaca, N.Y., 1979; pp: 90.

29. Tackholm, V. Students Flora of Egypt. 2 "d ed., Cairo Univ. Press. 1974; pp. 888.

30. Migahid, A. M. Flora of Saudi Arabia. 3nd ed. Vol. 1 and 2, King Saud Univ. Press. 1989.

31. Batanouny, K. G. Ecology and Flora of Qatar. Centre for Sci. and Applied Res. Univ. of Qatar, Alden press, Ltd. Oxford. 1981; pp 239.
32. AI-Hubaishi, A. \& Hohenstein, K. M. An Introduction to the Vegetation of Yemen. Ecological Basis, Floristic Composition and Human Influence. Deutsche Gesellschaftftlr Technische Zusammenarbeit (GTZ) GmbH. 1984; pp 209.

33. Mandaville, J. P. Flora of Eastern Saudi Arabia. Kegan Paul International Ltd. London and New York, 1990; pp 482.

34. Boulos,L. Flora of Egypt: volume four (Alismataceae- Orchidaceae). Al-Hadara publishing, Cairo, Egypt, 2005; pp:617

35. Boulos,L. Flora of Egypt: (Chacklist revised annotated Ed.). AlHadara publishing, Cairo, Egypt, 2009; pp:410

36. Whittaker, R. Gradient analysis of vegetation. Biol. Rev., 42: 207-264.

37. Smith, T. and M. Huston, 1989. A theory of spatial and temporal dynamics of plant communities. Vegetatio, 1967; 83: 49-69.

38. Gauch, H. Multivariate Analysis in Community Ecology. Cambridge University Press, Cambridge. 1982.

39. Ter Braak, C. Ordination. In: Jongman, R.H., Ter Braak, C.J., Van Tongeren, O.F. Eds.), Data Analysis in Community Ecology and Landscape Ecology. Cambridge University Press, Cambridge. 1995; pp: 91-173.

40. Schwartz, O. Flora des tropischen Arabien. Mitt. Inst, allg. Bot, Hamburg. 1939; 10: 1-393.

41. Newton, L. E. Phytogeographical Associations of the succulent plant Flora of South-West Arabia and the Horn of Africa. Nat. Cact. Succ. J. 1980; 35: 83-88.

42. Zohary, M. Geobotanical foundations of the Middle East. vol. 1-2 Gustav Fischer Verlag, Stuttg. 1973.

43. White, F. \& Leonard, J. Phytogeographical leaks between Africa and southwest Asia. Flora et Vegetatio Mundi. 1991; 9: 229-246.

44. Backeus, I. Distribution and Vegetation dynamics of humid savannas in Africa and Asia. J. of Veget. Sci. 1992; 3:345-356.

45. Vetaas, O. R. Gradients in field - layer vegetation on an arid misty mountain plateau in the Sudan. J. of Veget. Sci. 1992; 3: 527-534.

46. Barbour, M.G., Burk, J.H. \& Pitts, W.D. Terrestrial Plant Ecology, 2 Ed. California, London, Sydney:The Benjamin/Cummings Publishing Company. 1987; 634 pp.

47. Waisel, Y. Biology of Halophytes. Academic Press. New York and London. 1972; pp. 395.

48. Kassas, M. A. \& Zahran, M. A. Studies on the ecology of the Red Sea coastal land. II. The district from EI-GalalaEI-Qibliya to Hurghada. Bull. Soc. de Georaphie d'Egypt. 1965; 38: 155-193.

49. Zahran, M. A. Wet formations of the African Red Sea coast. In: V.J. Chapman (ed.): The Ecosystems of the world 1. Elsevier Scientific Publishing Company. 1977; pp. 215- 231.

50. Zahran, M. A. \& Mashally, I. A. Ecological notes on the flora of the Red Sea coastal land of Egypt. Bull. Fac. Sci. Mansoura Univ. 1991; 18: $251-292$

51. Danin, A. Desert Vegetation of Israel and Sinai. Jerusalem: Cana Publishing House. 1983; pp: 148.

52. Halevy, G. \& Orshan, G. Ecological studies on Acacia species in the Negev and Sinai. 1 - Distribution of Acacia raddiana and A. gerrardii spp. negevensis as related to some environmental factors. Israel J. Bot. 1972; 21: 197-208.

53. Frederiksen, P. \& Lawesson, J. E. Vegetation types and patterns in Senegal based on mulitivariate analysis of field and NOAA-AVHRR satellite data. J. of Veget. Sci. 1992; 3: 535- 544.

54. Ayyad, M. A. \& El-Ghareeb, R. Salt marsh vegetation of the western Mediterranean desert of Egypt. Vegetation. 1982; 49: 3-19.

55. Ayyad, M. The vegetation and environment of the western Mediterranean coastal land of Egypt. IV. The habitat of non-saline depressions. Journal of Ecology, 1976; 64: 713-722.

56. Parton, W., J. Stewart and V. Cole. Dynamics of C, N, P and S in grassland soils: a model. Biogeochemistry, 1988; 5: 109-131.

57. Raich, J., E. Rastetter, J. Melillo, D. Kicklighter, P. Steudler, B. Peterson, A. Grace, B. Moore III and C. Vorosmarty. Potential net primary productivity in South America: application of a global model. Ecological Applications. 1991; 1: 399-429.

58. Rastetter, E., M. Ryan, G. Shaver, J. Melillo, K. Nadelhoffer, J. Hobbie and J. Aber. A general biochemistry model describing the 
responses of the $\mathrm{C}$ and $\mathrm{N}$ cycles in terrestrial ecosystems to changes in CO2, climate and N deposition. Tree Physiology. 1991; 9: 101-126.

59. Sperry, J. and U. Hacke. Desert shrub water relations with respect to soil characteristics and plant functional type. Functional Ecology. 2002; 16: 367-378.

60. Zohary, M. Plant Life of Palestine, Israel and Jordan. Ronald Press, New York, 1962; pp: 262

61. Kassas, M. A. \& Imam, M. Habitat and plant communities in the Egyptian desert. III. The wadi-bed ecosystem. J. Ecol. 1954; 42: 424441.

62. Abd El-Ghani, M. Environmental correlates of species distribution in arid desert ecosystem of eastern Egypt. Journal od Arid Environments, 1998; 38:297-313.

63. Kassas, M. and K. Batanouny. Plant Ecology. In: CloudsleyThompson, J.J. Ed.), Sahara Desert. Pergamon Press, Oxford. 1984; pp: 348.

\section{Appendix}

Floristic List of the Recorded Species in Coastal Plains of Jazan region,Saudi Arabia.

1. Acanthaceae: Blepharis ciliaris CL.) B.L. Burtt

2. Aizoceae: Aizoon canariense L.; Tr anthema portulacasrrum L.

3. Amaranthaceae: Aeroa javanica (Burro. f.) Juss.; Amaranthus graecizans L.; Digera muricata (L.) Mart.

4. Aristolochiaceae: Aristolochia bracteolata Lain.

5. Asclepidaceae: Calotropis procra (/kit.) Ait f.; Caralluma penicillata (Deft.) N.E. Br.;Leptadenia pyrotechnica (Forssk.) Decne.

6. Boraginaceae: Heliotropium arbainense Fresen.

7. Capparaceae: Capparis decidua (Forssk.) Edgew.; Capparis spinosa L.; Cleome viscosa L.;Dipterygium glacuum Decne.; Crynandropsis gynandra (L.) Briq.

8. Chenopodiaceae: Halopeplis perfoliata (Forssk.) Bunge ex Schweinf.; Suaeda monoica Forssk.

9. Commelinaceae: Aneilema taca zeanum Hochst. ex. C.B. C1.

10. Compositae: Launaea sp.; Xamhium spinosum L.

11. Convolvulaceae: Cressa crerica $L$.

12. Crucfferae: Anastatica hierochuntica L:; Savignya parviflora (Del.) Webb Schouwia thebaicaWebb

13. Cucurbitaceae: Citrullus colocymhis (L.) Schrad.

14. Cyperaceae: Cyperus conglomeratus Rottb.

15. Euphorbiaceae: Euphorbia hirta L.; Euphorbia articulata L.; Euphorbia prostrata Ait.;Euphorbia aculeata L.; Jatropha glauca Vahl

16. Gramineae: Aduropus lagopoides (L.) Trill. ex Thw.; Aeluropus littoralis (Gouan) Parl.;Cenchrus ciliaris L.; Chloris virgata Sw.; Crypsis aculeata (L.) Alton; Cutandia dicotoma (Forssk.) Trabut; Cutandia memphitica (Spreng.) Benth.; Dacryloctenium ae ptium (L.) $P$. Beauv.; Digitaffa ciliaris (Retz.) Koel; Digitaria sanguinalis (L) Scop.; Echinochloa colona (L.) I.£mk; Eragrostis cilianensis (All.) Vign.-Lut.; Imperata cylindrica (L.) Raeusch; Panicum repens L.; Panicum turgidum Forssk.; Phalaris minor Retz.; Polypogon monspeliemis (L.) Desf.; Rosrraria cristata (L.) Tzvelev.; Setaria verticillata (L.) P. Beauv.; Setaffa viridis (L.) P. Beauv.; Sorghum bicolor (L.) Moench; Sporobolus plumosa (L.) Munro ex T. Anders.; Sporobolus spicatus (Vahl) Kunth; Sporobolus virginicus (L.) Kunth

17. Leguminoseae: Acacia ehrenbergiana Hayne; Acacia mellifera (Vahl) Benth.; Acacia raddiana Savi; Acacia torrilis subsp, radiana (Forssk.) Hayne; Indigofera hochstetteri Baker; Indigofera spinosa Forssk.; Rhynchosia minima (L.) DC. vat. memnonia (Del.) Cooke.; Senna alexandrina Forssk.; Senna italica Mill.; Tephrosia apollinea (Del.) Link; Trigonella hierosolymitana Boiss.

18. Liliacea: Aloe vera $L$.
19. Malvaceae: Abutilon pannosum (Forst. f.) Schlecht.

20. Portulacaceae: Portulaca oleraceae $L$.

21. Rhamnaceae: Ziziphus spina-christi (L. ) WiUd.

22. Salvadoraceae: Salvadora persica $L$.

23. Scrophulariacaea: Striga hermomhica Benth.

24. Solanaceae: Datora innoxia Mill.; Datora stramonium L.; Lycium shawii Roem. \& Schult.; Solanum incanum L.; Solanum nigrum L.

25. Tamaricaceae: Tamarix mannifera (Ehrenb.) Bunge

26. Tiliaceae: Corchorus depressus (L.) Stocks

27. Urticaceae: Urtica urens $L$.

28. Vitaceae: Cissus quadrangularis $L$.

29. Zygophyllaceae: Fagonia bruguieri DC.; Fagonia indica Burro. f.; Tribulus pentandrus Forssk.; Tribulus terrestris L.; Zygophyllum album L.; Zygophyllum simplex $L$.

\section{How to cite this article:}

Salman A. A. Correlation Between Plant Distribution and Edaphic Factors in Coastal Plains of Jazan Region, Saudi Arabia. J App Biol Biotech. 2015; 3 (03): 042-049. 